\title{
SYNOPTIC EVENTS ASSOCIATED WITH THE LAND SURFACE TEMPERATURE IN RIO DE
} JANEIRO

\author{
EVENTOS SINÓPTICOS ASSOCIADOS DA TEMPERATURA SUPERFÍCIE DA TERRA NO RIO DE \\ JANEIRO
}

\section{Rafael Coll DELGADO' ${ }^{1}$; José Francisco de OLIVEIRA-JÚNIOR ${ }^{2}$; Givanildo GOIS ${ }^{3}$; Rafael de Ávila RODRIGUES ${ }^{4}$; Paulo Eduardo TEODORO ${ }^{\text {* }}$}

1. Universidade Federal Rural do Rio de Janeiro, Seropédica, RJ, Brasil; 2. Universidade Federal de Alagoas, Maceió, AL, Brasil. 3. Universidade Federal Fluminense, Volta Redonda, RJ, Brasil; 4. Universidade Federal de Goiás, Catalão, GO,

Brasil. 5. Universidade Federal de Mato Grosso do Sul, Chapadão do Sul, MS, Brasil. eduteodoro@ hotmail.com

\begin{abstract}
This article aimed to evaluate land surface temperature using MOD11A2 (Terra satellite) with spatial resolution of one kilometre, compares its findings with land surface temperature data gathered by conventional meteorological stations, and, finally, investigates relations between land surface temperature and synoptic systems events that occurred in Rio de Janeiro State between January until December of 2009. The highest surface temperatures recorded by the MOD11A2 product, derived from the MODIS sensor, were found in the Metropolitana, Baixadas Litorâneas, Norte Fluminense and Noroeste Fluminense regions of Rio de Janeiro State and were recorded during the summer, winter and spring seasons. Autumn was the only exception, and this was due to the influence of the coastal environment. The following synoptic systems interfered with the estimated surface temperature produced by the MOD11A2 product for Rio de Janeiro State in 2009: the Madden Julian Oscillation and South Atlantic Convergence Zone in the summer; and Frontal Systems, the South Atlantic Convergence Zone, the Madden Julian Oscillation and the Upper Tropospheric Cyclonic Vortex in spring. The land use and occupation types with the highest surface temperature are: forest, urban area and pasture land in the summer; forest, urban area, agriculture and pasture land in autumn; and urban area and agriculture during spring. The MOD11A2 product showed a drastic decrease of the surface temperature for all land types during winter, especially for forested land.
\end{abstract}

KEYWORDS: Southeast region. Remote sensing. Thermal field. Meteorological satellite.

\section{INTRODUCTION}

Worldwide urbanization and population growth, and the ways in which they have changed the use and occupation of land, are thought to be probable causes of global warming. These processes do not only alter the landscape: anthropic activities also contribute to greenhouse gas emissions (GGE) which affect global warming (SATTERTHWAITE, 2008). The urbanization process produces greater changes in land surface and atmospheric properties, such as the energy partitioning between urban and adjacent areas, thus creating a new urban climate (OKE et al., 1992).

Changes to the land surface, such as urbanization, substitute natural surfaces for buildings, roads and streets, significantly increasing the level of soil waterproofing as well as altering its thermal properties (e.g. specific heat and thermal conductivity) and radioactivity (e.g albedo) (ANJOS et al., 2013). As a consequence, there have been an increasing number of floods as well as changes in radiation and energy surface balance. In the last few years, urbanized areas have seen an increase in concentrated heat (the phenomenon known as the urban heat island effect), linked to a rise in severe rainfall, and it is fast becoming a significant problem for affected populations and policy makers (RAMANATHAN; FENG, 2009).

The process of urbanization alters the Surface Energy Balance (SEB), and does so as much for short as for long wavelength radiation emission. The thermal properties of the materials used in urban building and construction promote faster heat conduction than that of soil and vegetation in rural areas, thus contributing to increasing dissimilarity of temperature between urban and rural regions (FREITAS; DIAS, 2005). Surface temperature is directly influenced by climate variation, and precise evaluation is of great importance for research monitoring spatial dynamics such as urbanization processes, natural catastrophes or other landscape changes. The decrease of green areas creates changes in the local atmosphere, thus modifying patterns of temperature, rain, and wind direction and speed (KATO; YAMAGUCHI, 2005).

When using the data gathered by the Thematic Mapper (TM) to study the influence of landscape change in Cruzeiro do Sul, in the Brazilian State of Acre, Delgado et al. (2012) found an increase in the number of anthropised areas between 2005 and 2010. These researchers also established another important result: they noted that 
areas transformed by human action had seen temperature increases, with values reaching $40^{\circ} \mathrm{C}$ and above, something which contributed to an increase in precipitation of $17.6 \mathrm{~mm}^{-1}$.year ${ }^{-1}$ (19711990) and reached a maximum value of $30.5 \mathrm{~mm}^{-}$ ${ }^{1}$.year ${ }^{-1}$ between 1993 and 2002.

Against that background, this article aimed to evaluate land surface temperature using MOD11A2 (Terra satellite) with spatial resolution of one kilometre, compares its findings with land surface temperature data gathered by conventional meteorological stations, and, finally, investigates relations between land surface temperature and synoptic systems events that occurred in Rio de Janeiro State between January until December of 2009.

\section{MATERIAL AND METHODS}

\section{Characterization and location of the research area}

This research examined Rio de Janeiro State, which is located in the Southeast region of Brazil, in the country's east coast, and between the meridians $40^{\circ} 57^{\prime} 59^{\prime}$ ' $\mathrm{W}$ and $44^{\circ} 53^{\prime} 18^{\prime \prime} \mathrm{W}$, and parallels $20^{\circ} 45^{\prime} 54^{\prime \prime} \mathrm{S}$ e $23^{\circ} 21^{\prime}$ 57" S (Figure 1). Rio de Janeiro State shares borders with Espírito Santo State in the northeast, with Minas Gerais State in the north and northwest, with São Paulo State in the southeast, and with the Atlantic Ocean in the south and east. The Conventional Meteorology Stations belong to the National Institute of Meteorology (INMET) and are spatially distributed so as to represent the physiographic conditions of the State. Rio de Janeiro State has a territorial area of $43,780.172 \mathrm{~km}^{2}$, and a population of $15,993.583$ in habitants. The state is geopolitically divided into 92 municipalities, which are grouped together into eight different meso-regions (subdivisions of Brazilian States): Norte Fluminense, Noroeste Fluminense, Serrana, Centro Sul Fluminense, Baixadas Litorâneas, Metropolitana, Médio Paraíba and Costa Verde (IBGE, 2013).

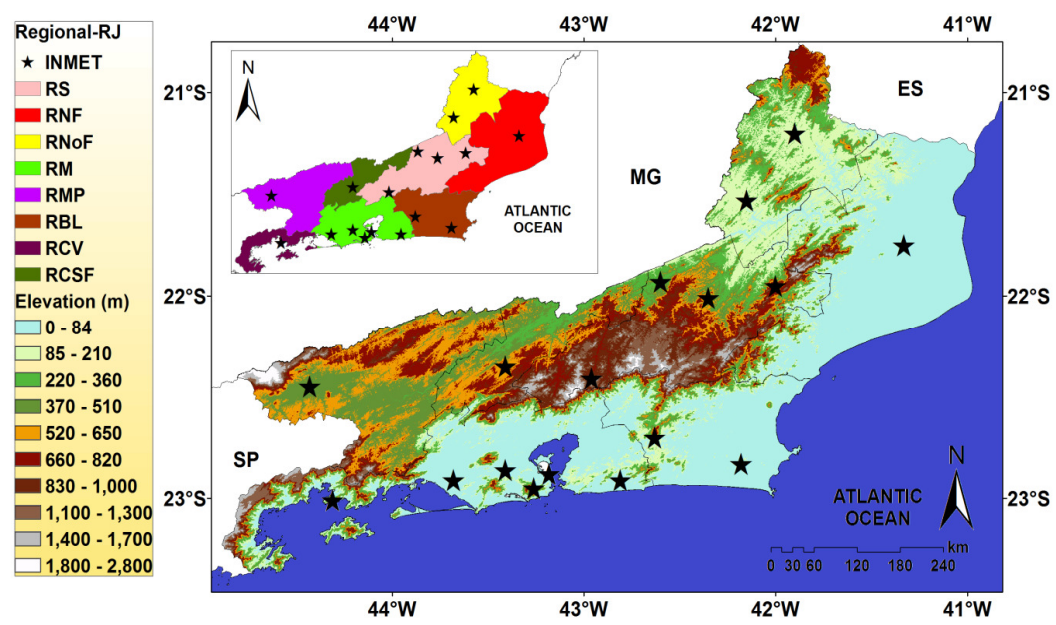

Figure 1. Hypsometric map (m) obtained from SRTM. Mesoregion classification and the INMET conventional meteorological stations used in 2009 in Rio de Janeiro State.

\section{Air temperature data series (2009)}

We used 2009 daily time series data gathered from seventeen stations for a specific day of the year (astronomic day of the year) to evaluate the evolution of the air temperature recorded by the INMET Conventional Meteorological Stations. The analysis of maximum and minimum air temperature was conducted between January until December 2009. We then obtained the mean value representing the average time of the satellite passing over the state of Rio de Janeiro, which was at 10:30 Local Standard Time (LST). Images from the MOD11A2
MODIS product, with spatial resolution of $1 \mathrm{~km}$, were acquired for the same period.

\section{Analysis of land surface temperature recorded by MOD11A2 and SRTM}

In order to conduct this study, we used twelve monthly images (January until December 2009) gathered by the MOD11A2 MODIS product (Land Surface Temperature), onboard the Terra satellite. The product has 8-day data composed from the daily $1 \mathrm{Km}$ resolution imagery These images were obtained from NASA (National Aeronautics and Space Administration), USGS (U.S. Geological 
Survey) and EROS (Earth Resources Observation and Science Center) on the $8^{\text {th }}$ September 2013. They can be found at the following web address: $<$ glovis.usgs.gov>.

The images are in the Hierarchical Data Format (HDF) and Sinusoidal projection. It was necessary to convert the HDF format into GEOTIFF and the Sinusoidal projection into UTM WGS 84 for the images to be processed by the ArcGis 10.2. To achieve this, we had to pre-process the images using the Modis Projection Tool (MRT) algorithm. The MRT is a software tool exclusively designed to work with MODIS images. When working with this software, we chose the 'LST_Day_1km' image, and also selected the geographic position and the UTMWGS84 projection parameter.

The Tile (a subdivision of the available areas of MODIS Products) which includes Rio de Janeiro state was the H13V11 and H14V11, with a total of 24 images used to cover the period of 2009. The MOD11A2 product (Land Surface temperature - LST) is derived from the MODIS sensor, one of the best sensors for radiometric resolution in the collection 5 of the thermal band, with spatial resolution of $1 \mathrm{~km}$. The sensor uses the LST algorithm, including the Day/Night LST algorithm (WAN, 2007), to produce data on land surface temperature. This algorithm was specifically developed for MODIS and produces daytime and night-time thermal images for the whole surface of the Earth. Daily periodicity is validated by the MAS (MODIS Airborne Simulator) images and by field measurements conducted between 1996 and 1998 (WAN et al., 1998). The MOD11 product incorporates, in its algorithm emission data, viewing angle (developed to correct atmospheric effects), information on the surface reflectivity, emission, absorption and atmospheric dispersion, as well as information on solar radiation on the day. The A2 product is a composition of eight days, produced after the daily data generated by the A1 product. We chose to use collection 5 as it has improved methodological capabilities when compared to collection 4 (WAN, 2007).

A few data adjustments are necessary before applying the land surface temperature model. As they are pre-processed products, they are often available in a 16 bit format, so that in order to employ them they first need to be converted into their respective units. This was done by applying the ArcGIS 10.2 Spatial Analyst Tools - with a Raster Calculator in the Map Alebra toolset. Finally, in order to utilize the 16 bit MOD11A2 product, we also had to convert it to Kelvin $\left(\mathrm{T}_{\mathrm{K}}, \mathrm{K}\right)$ (Equation 1).
$\mathrm{T}_{\mathrm{K}}=\mathrm{ND} * 0.02$

ND is the Digital Number (MOD11A2) and 0.02 is the constant used in converting to Kelvin.

After converting the MOD11A2 product to temperature values in Kelvin, we used the ArcGIS 10.2 software to work on the vector data, database, calculation of the surface temperature and map creation. We also used images generated by radar, which were obtained by the sensors aboard the Endeavour space shuttle, installed for the SRTM (Shuttle Radar Topography Mission) project. We used the ERDAS IMAGINE software to produce a mosaic of Rio de Janeiro State. The SRTM Elevation Digital Model, with 3 arc seconds (about $90 \mathrm{~m}$ spatial resolution) is available free from the American government (MIRANDA, 2013).

We used the ArcsGIS 10.2 Geographically Weighted Regression tool for a multiple linear regression analysis of the independent variables (latitude, longitude and altitude) to enable to evaluate the dependable variable (the land surface temperature of the MOD11A2 product). The analysis employed the following equation:

$\mathrm{T}_{\mathrm{Si}}=\beta_{0}+\beta_{1}$ Lat $_{\mathrm{i}}+\beta_{2}$ Long $_{\mathrm{i}}+\beta_{3}$ Alt $_{\mathrm{i}}+\varepsilon_{\mathrm{i}}$

(2)

In the above equation, $\mathrm{T}_{\mathrm{Si}}(\mathrm{K})$ is the land surface temperature; Lat $\mathrm{t}_{\mathrm{i}}$ (degrees and tenths) is the latitude; Long $\mathrm{i}_{\mathrm{i}}$ (degrees and tenths) is the longitude; Alt $_{\mathrm{i}}(\mathrm{m})$ is the altitude; $\beta_{0}, \beta_{1}, \beta_{2}, \beta_{3}$ are the regression coefficients; and $\varepsilon_{\mathrm{i}}$ is the random error, independently assumed and with normal distribution, zero mean and constant variation.

We considered the negative sign of longitude and latitude to represent west from the Greenwich and South Hemisphere.

\section{Statistical methods}

We have used statistical methods available in the current literature to evaluate the performance of the methodology applied in our research. They are based on comparative analyses of the proposed methodology and the data gathered from the Automatic Meteorological Station. We applied the determination coefficient $\left(r^{2}\right)$, followed by the estimated mean standard error (SEM, ${ }^{\circ} \mathrm{C}$ ) (ALLEN et al., 1989), mean bias ( $\left.\mathrm{MB}{ }^{\circ} \mathrm{C}\right)$ and index of agreement (d) proposed by Willmott et al. (1985).

\section{Land use and occupation}

During the seasonal evaluation of the land surface temperature, we tried to verify the relationship between land temperature and the different forms of soil usage found in Rio de Janeiro State by using the data supplied by the 
Environmental State Institute (Instituto Estadual do Ambiente - INEA) website (web address: http://www.inea.rj.gov.br/basetematica_estadoambie nte/). We selected four types of land use in the ArcGIS 10.2 software: forest, pasture, urban area and agriculture. For this purpose, we used the spatial analysis and data extraction tools. We then analysed the seasonal variations for the different classes and the information obtained for land surface temperature. Afterwards, we conducted an exploratory analysis of the data by using box-plots, which allowed us to visualise the location, dispersion, symmetry, outlier barriers as well as the outliers themselves, independently from the form of the distribution of the dataset.

\section{Description of the meteorological events between January until December 2009}

Based on the data gathered from the CLIMANÁLISE bulletins, we conducted a study of the main synoptic systems' events that occurred in Rio de Janeiro State in 2009 (CPTEC, 2013). We then described the synoptic systems according to their influence on the variability of the land surface temperature, data which was gathered from the MOD11A2 during the days the Terra satellite passed over during the seasonal scale period.

\section{RESULTS AND DISCUSSION}

\section{Algorithm test}

The dispersion in the surface temperature estimates was high for every month of the year, as indicated by values for the determination coefficient $\left(\mathrm{r}^{2}\right)$ of between 0.11 (October) to 0.52 (November) (Table 1). High dispersions in values suggest a significant contribution of non systematic errors (WILLMONTT, 1981). Highest dispersions in the estimates (higher than $\mathrm{r}^{2}$ ) were observed during the change between winter (August) and spring (September and October) with com $r^{2}<0.19$, and the smallest dispersions $\left(r^{2}>0.49\right)$ during autumn (April and May) and in November. Even though the dispersion in the estimates was high, as indicated by the low $r^{2}$, the standard error of the estimate was below 3.8K (October), representing less than 1.5\% of the average value of the estimated surface temperature. In absolute terms, the months of January and February (summer months) and October (spring) had the highest value standard error of the estimate $(>3.1 \mathrm{~K})$, whereas we recorded the lowest values $(<2.2 \mathrm{~K})$ during the transition between autumn and winter (April and May) and in winter (June and July). The mean (Standard Error of the Estimate/average) of January and October presented the highest errors, 1.15 and $1.29 \%$ respectively, and the lowest errors $(<0.76 \%)$ occurred during the autumn months and in June. The average tendency was towards over estimation (Figure 3), with the exception of July, October and December, where there was an overestimation for values lower than 307K (December), $296 \mathrm{~K}$ (July) and $303 \mathrm{~K}$ (October) and underestimation for higher values.

Table 1. Statistical analysis of the land surface temperature $(\mathrm{K})$ and the MOD11A2 product data for the period of January to December 2009 in Rio de Janeiro State.

\begin{tabular}{ccccccc}
\hline Month & EPE $(\mathrm{K})$ & $\mathrm{VM}$ & $\mathrm{a}(\mathrm{K})$ & $\mathrm{b}$ & $\mathrm{r}^{2}$ & $\mathrm{~d}$ \\
\hline Jan & 3.44 & 0.1937 & 16.28 & 0.957 & 0.28 & 0,49 \\
Feb & 3.11 & 0.0554 & -50.25 & 1.170 & 0.29 & 0,60 \\
Mar & 2.83 & 0.1741 & 70.17 & 0.777 & 0.27 & 0,51 \\
Apr & 1.73 & 0.0680 & 81.27 & 0.737 & 0.50 & 0,77 \\
May & 1.83 & 0.1925 & 60.37 & 0.801 & 0.49 & 0,58 \\
Jun & 2.24 & 0.0639 & 25.39 & 0.917 & 0.38 & 0,73 \\
Jul & 1.75 & 0.0234 & 148.86 & 0.498 & 0.35 & 0,93 \\
Agu & 2.48 & 0.1899 & 176.22 & 0.415 & 0.16 & 0,52 \\
Sep & 2.70 & 0.1499 & 78.15 & 0.747 & 0.19 & 0,49 \\
Oct & 3.83 & 0.1706 & 186.57 & 0.383 & 0.11 & 0,55 \\
Nov & 2.33 & 0.3551 & -107.26 & 1.377 & 0.52 & 0,38 \\
Dec & 2.48 & 0.1816 & 163.17 & 0.468 & 0.27 & 0,64 \\
\hline
\end{tabular}

Values for the month of July showed high agreement between the estimates and the observed data, confirmed by the Willmott coefficient of agreement (d) of 0.93; followed by April with 0.77 
and June with 0.73. We observed the lowest agreement values $(<0.49)$ during January and in spring (September and November). The lower levels of precision and agreement of the estimates in the spring and summer months are due to the highest measures of rainfall being recorded during this period in Rio de Janeiro State. Rainfall during these seasons is highly variable spatially and in terms of intensity due to the tropical convection system that intensifies the atmospheric systems related to the rain (e.g. the Frontal Systems and the South Atlantic Convergence Zone) and to the mesoscale connective systems (ANDRÉ et al., 2008). On the other hand, during the autumn and winter months, the total amount of rainfall is less than that in summer and spring and is mainly related to frontal systems, which are less spatially variable.

Although the values for $\mathrm{r}^{2}$ for January, February, May and June were lower than 0.38 and the standard error of the estimate was higher than $1.8 \mathrm{~K}$, the angular regression coefficient (b) for the observed data and estimated data was close to 1 (0.92 in June and 1.17 in February). This result indicates the scale of the contribution of the proportional systematic error in the estimates (WILLMOTT, 1985), seen in the regression lines found approximately parallel to the line 1:1 (Figure 2 - Summer and Winter). The autumn months (March and May) and the spring months (September and November) showed similar results, in other words, a significant contribution due to proportional systematic error. However, the difference between the ideal value was higher: $0.747<b<1.377$. Thus, even though there had been a significant contribution due to proportional systematic error, the results showed that this contribution was less than that observed for January, February, May and June. The systematic error can be related to the algorithm (e.g. algorithm parameterization) applied to surface temperature, or to the systematic errors of the MOD11A2 MODIS product utilized for the research.

In the multiple linear regression analysis, altitude was the most significant variable in the model, explaining $64 \%$ of the variability in land surface temperature in the State of Rio de Janeiro. When latitude and longitude were added, the final $\mathrm{r}^{2}$ was of $0.71(71 \%)$. Thus, latitude, longitude and altitude variables explained $71 \%$ of the spatial variability of annual land temperature measurements. In ANOVA $p<0.05$ the model was significant. Similar results using digital elevation models (SRTM) and air temperature were found by Lyra et al. (2011) and Oliveira et al. (2013). Figure 2 showed that the algorithm applied to determine the land surface temperature, by using the images from MOD11A2 MODIS product, had the best mean statistical indexes for autumn and winter when compared to the data gathered by the Conventional Meteorological Stations in Rio de Janeiro State. Wienert and Kuttler (2005) showed that there is a close relationship between the intensity of UHI with latitude, where at low latitudes the average intensity observed is about $4^{\circ} \mathrm{C}$, which increases toward high latitudes with average of about $6.1^{\circ} \mathrm{C}$. The authors explain these variations by the increase of anthropogenic heat in high latitudes and also by the differences in surface energy balance between these regions.
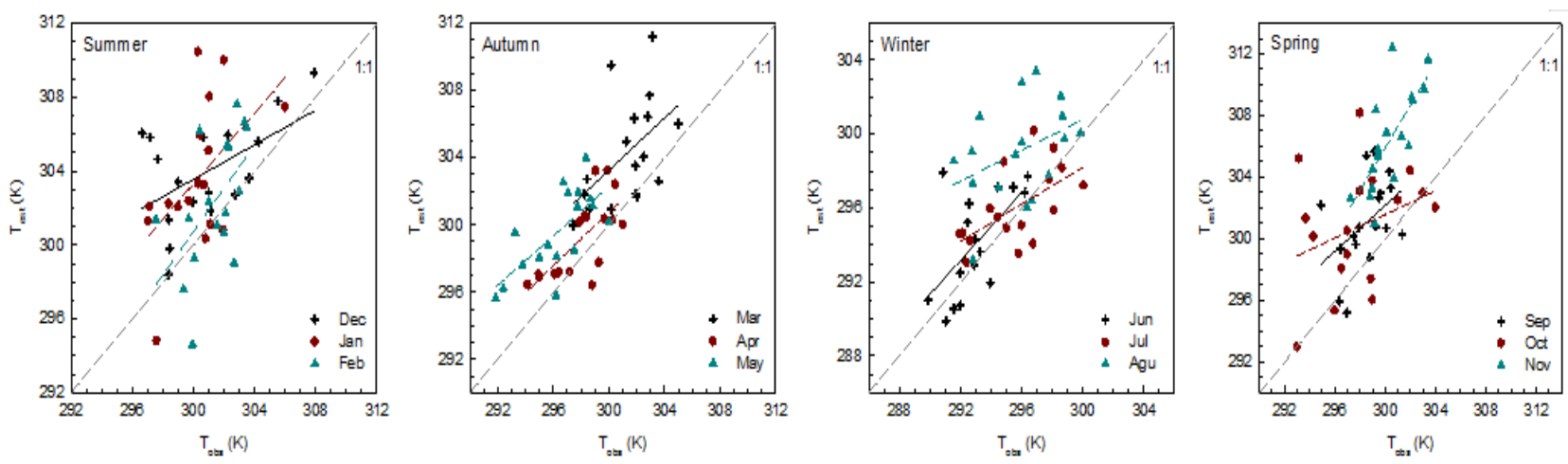

Figure 2. The relationship between the air temperature $(\mathrm{K})$ recorded by the conventional meteorological stations and the estimated temperature (K) produced by the MOD11A2 MODIS product aboard the Terra satellite for 2009 summer, autumn, winter and spring in Rio de Janeiro.

\section{Space-time distribution of surface temperature}

The highest surface temperatures obtained by the MOD11A2 product in the summer were within 307 to $310 \mathrm{~K}$. These were observed in the
Metropolitana, Baixada Litorânea, Norte Fluminense and Noroeste Fluminense regions of Rio de Janeiro, and coincided with areas of lesser altitude $(<90 \mathrm{~m})$, located at the windward side of the 
main mountain ranges, and which were characterized by the influence of air temperature patterns. The lower surface temperatures were within 296 and $298 \mathrm{~K}$ and found in the mountain areas of the Costa Verde, Centro Sul Fluminense and Serrana regions. Thus, the higher (and lower) temperatures were conditioned by the higher (and lower) altitudes found in the state, indicating geographical influence on the distribution of surface temperature. Lyra et al. (2011) observed that, in a tropical region, altitude is the main geographical factor (latitude, longitude and altitude) affecting the distribution of air temperature. With a high temperature nucleus, the Metropolitana region was the only exception to these findings, reflecting the scale of the urbanised areas in this region, itself a consequence of the high level of industrialization. The findings of the MOD11A2 product confirmed that the Metropolitana region had higher surface temperatures. Again, this is because of the scale of the urbanized area when compared to the Baixada Litorânea, Norte Fluminense and Noroeste Fluminense regions and which, consequently, results in the increase of the albedo caused by this change in the use and coverage of land in the region. The increase in temperature, moreover, is also caused by the influence of urban heat island formation in the region (ZERI et al., 2011).

The thermal amplitude decrease among the mesoregions of Rio de Janeiro was determined based on the following physiographical factors: proximity to the Atlantic Ocean and influence of the mountain ranges in relation to the flow patterns (leeward and windward) which interfere with the surface temperature. We observed, across the land surface, an increase in temperature during the summer period. However, due to their position, the windward regions of the mountain ranges (Serra do Mar and Serra da Mantiqueira) receive higher amounts of solar radiation than that of the leeward regions. This process was responsible for the formation of a horizontal gradient in the surface temperature. Finally, an important additional factor is that the mesoregions of the state have varied use and land occupation characteristics, including urban areas, pasture areas through to areas of native vegetation, which imply different regimes of surface temperature.

Figure $3 \mathrm{a}$ shows the composition of the MODIS product during the days of flight of the Terra satellite in the summer. The Southeast region experienced storms and heavy rainfall in December, especially because of the Madden-Julian Oscillation (MJO), which was responsible for the occurrence of these events in Rio de Janeiro State, which was then followed by the South Atlantic convergence zone (SACZ) episode in the same month. While January thus saw two SACZ episodes in the region, the second one was weaker, which contributed to the formation of milder air temperatures along the Southeast coast region. February did not see Frontal Systems affecting the state, only the south part of the country, and that is due to the anomalous anticyclone activity in the east part of Brazil, which had the consequence of increasing the air temperature in this area. Climatologically speaking, we noted that January and February saw the intensification of the La Niña phenomenon, while December saw the beginning of the El Niño phenomenon. The summer season was characterised by a powerful drought and positive anomalies in air temperature, even though there had been variability in the systems creating and inhibiting rain in the Southeast region (CPTEC, 2013).

In contrast to the summer season, autumn saw the highest surface temperatures recorded by the MOD11A2 product in all the regions of Rio de Janeiro State. The temperatures reached between 299 and $300 \mathrm{~K}$ to 307 and 309K. The exceptions were the Serrano and Costa Verde regions, which recorded surface temperatures between 293 and $294 \mathrm{~K}$. These two regions have extended green areas and little urbanization, which contribute to a smaller variation of albedo and milder surface temperatures. Only the coastal region observed a strong horizontal gradient in surface temperature. The high temperatures recorded throughout Brazil are thought to be responsible for this exceptional difference between the seasons, with maximum and minimum temperatures above the recorded national historical average levels, especially in the Southeast region (CPTEC, 2013).

Figure $3 b$ shows the composition of the MODIS product when the Terra satellite passed over the state in autumn. No Frontal Systems were acting in the Southeast region in March, only two SACZ episodes. These two SACZ events contributed to a higher accumulation of precipitation in the Brazilian Southeast region, and particularly in the north part of Rio de Janeiro State. April had rainfall below the average for the period and this is because the center of the Subtropical Anticyclone of the South Atlantic (SASA) moved to the central and coastal parts of the Southeast region. The Bolivian High synoptic system was also contributed to the decrease in rainfall. 

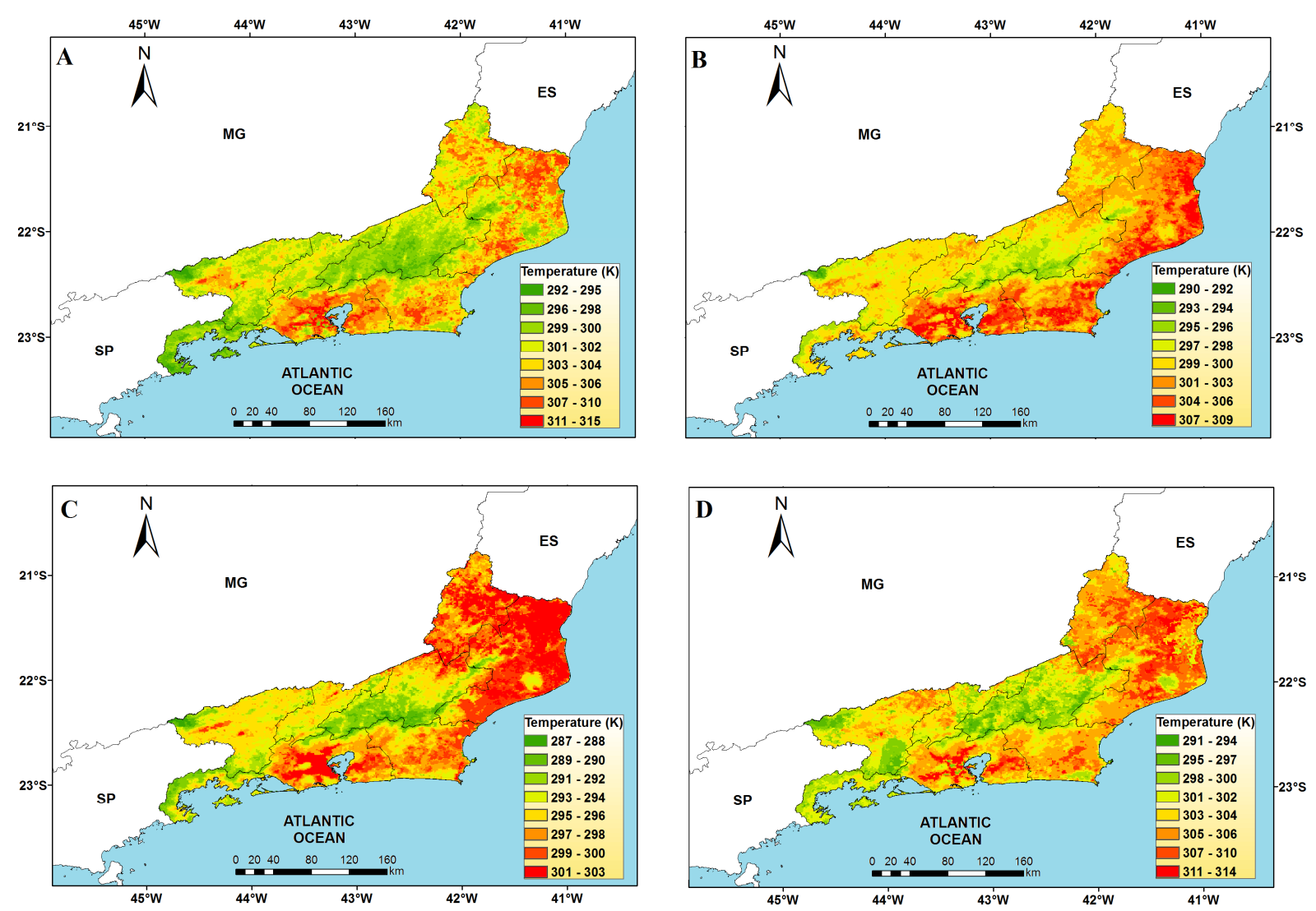

Figure 3. Surface temperature $(\mathrm{K})$ recorded by the MOD11A2 MODIS product aboard the Terra satellite for 2009 summer (A), autumn (B), winter (C) and spring (D) in Rio de Janeiro.

Due to the low activity of the Frontal Systems and the presence of the Upper Tropospheric Cyclonic Vortex, the Southeast region of Brazil continued to see scarce rainfall in May (CPTEC, 2013), with the Upper Tropospheric Cyclonic Vortex characteristically provoking subsidence movement in its peripheral area. These synoptic systems contributed to the increase in the superficial thermal field of Rio de Janeiro State. Finally, during the autumn period, the small Frontal Systems activity, the SASA and the Upper Tropospheric Cyclonic Vortex, all contributed to increases in the surface temperature in the greater part of the mesoregions of Rio de Janeiro State.

The highest surface temperatures recorded in the winter by the MOD11A2 product were within 301 and $303 \mathrm{~K}$, especially in the Metropolitana, Baixada Litorânea, Norte Fluminense and Noroeste Fluminense regions of Rio de Janeiro; the highest values were in the Norte Fluminense and Noroeste Fluminense regions. The lowest surface temperatures recorded were between 289 and $290 \mathrm{~K}$ in the Costa Verde and Serrana regions. Centro Sul
Fluminense and Metropolitana regions were the exceptions with high surface temperatures. The leeward and windward flow of the mountain ranges, as well as the solar radiation, both impacted on surface temperature during this season. Similarly, to the autumn season, the winter saw only the coastal region developing a strong horizontal gradient in surface temperature, a development which started in the Metropolitan Region (Figure 3c).

According to established patterns, part of the land surface should cool down during the winter months. However, the conditions for the meaningful increase of land surface temperature seen in the mesoregions of Rio de Janeiro State are related to a hot and dry air mass remaining over the Central and Southeast regions of Brazil during June, which, as consequence, contributed to the increase of temperatures in these regions. The Southeast region still saw rainfall in July due to the Subtropical Jet (SJ), favoring the intensification of the Frontal Systems, however, this only happened in two cases. In August the drought period followed the normal 
pattern for the Central and Southeast regions (CPTEC, 2013).

The MOD11A2 product recorded the highest surface temperatures in spring, between 307 to $310 \mathrm{~K}$ and 311 to $314 \mathrm{~K}$, a pattern different to that seen in all the previous seasons observed. Again, discrepancies were seen in the Metropolitana, Baixada Litorânea, Norte Fluminense, and Noroeste Fluminense regions of Rio de Janeiro, and, when compared to the summer period, spring showed variability in the superficial thermal field and further increases in surface temperatures. The lowest surface temperatures were between 298 and $300 \mathrm{~K}$ in the Costa Verde and Serrana regions. The exceptions were Centro Sul Fluminense and Médio Paraíba regions, with high and low surface temperatures between 291 and 291 $\mathrm{K}$. In contrast to the other seasons, there was no formation of strong horizontal gradients in surface temperature along the coastal region (Figure 3d).

Spring was marked by increases in the warmth of parts of the land surface. In September, the Frontal Systems moved along the interior and coastal areas of the Southeast region of Brazil, generating conditions favorable the increase of rain in the central-south part of Rio de Janeiro State. The Frontal Systems incursion, followed by a trough in the medium and high troposphere, all helped to form areas of instability. These areas of instability contribute to the increase of the total accumulation of rainfall, especially in the north region of Rio de Janeiro State. Madden-Julian Oscillation, again, brought rainfall in the second half of October. During this month the convection system was mainly associated with SACZ and with the joint incursion of Frontal Systems. It should be pointed out, however, that spring is the season with the highest numbers of Frontal Systems in Rio de Janeiro State (ZERI et al., 2011). Finally, November did not see the occurrence of rain in the Southeast region of the country, as there was no SACZ, and only the Bolivian High and Upper Tropospheric Cyclonic Vortex influenced rain and air temperature patterns across this period (CPTEC, 2013).

During the summer, agricultural land had the smallest surface temperature maximum value $(313 \mathrm{~K})$, while forest, urban and pasture land types had higher values $(315 \mathrm{~K})$. The use and occupation of land as seen by agriculture and urban areas had the highest quartiles, $299.3 \mathrm{~K}$ and $299 \mathrm{~K}$ respectively, whilst the forest land type showed the smallest mean values in the exploratory data analysis, with $303 \mathrm{~K}$. For values that are above the average in the third quartile analysis, the agriculture and forest land types had the smallest values, 307.8 $\mathrm{K}$ and $308.5 \mathrm{~K}$ respectively. There is a direct relationship between increases in the air temperature and the photoperiod in the summer season, as seen by the increase of energy output for these land types. In autumn, the smallest mean found was that of the forest land type. Generally speaking, those land types with the highest temperatures are the anthropised areas (urban and agricultural areas) followed by pasture land.

In the exploratory data analysis forest land has the smallest magnitudes, followed by pasture land (Figure 4). The areas classified as dense green, with good amounts of shade and water over the ground or at the tree canopy, helped to decrease the surface temperature, presenting lower temperatures when compared with other land types. Forest and pasture land had the lowest average (302 K) during spring. Urban areas and agriculture land had the highest average values, $302 \mathrm{~K}$ and $303 \mathrm{~K}$ respectively. Both land types saw maximum and minimum values varying from $291 \mathrm{~K}$ to $314 \mathrm{~K}$. Agriculture land was the highest in the third quartile with values above the $308 \mathrm{~K}$ average.
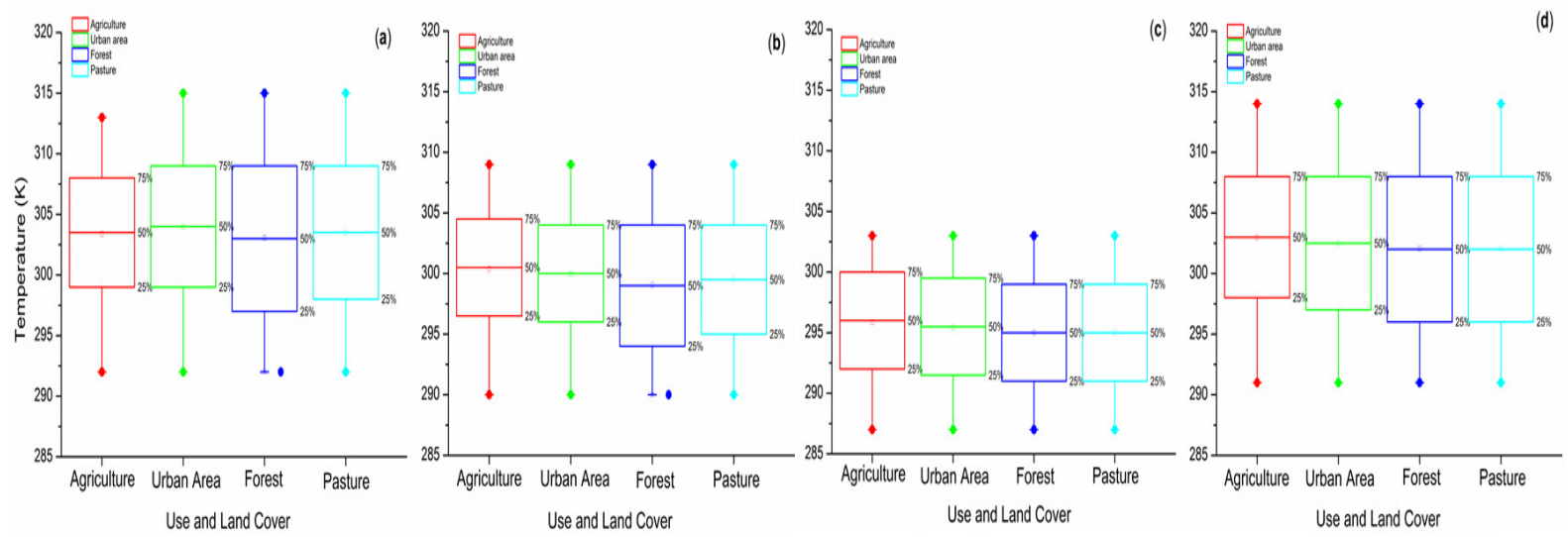

Figure 4. Box-plot of the categories of land use for summer (a), autumn (b), winter (c) and spring (d) in 2009 in Rio de Janeiro. 


\section{CONCLUSIONS}

The highest surface temperatures recorded by the MOD11A2 product, derived from the MODIS sensor, were found in the Metropolitana, Baixadas Litorâneas, Norte Fluminense and Noroeste Fluminense regions of Rio de Janeiro State and were recorded during the summer, winter and spring seasons. Autumn was the only exception, and this was due to the influence of the coastal environment.

The following synoptic systems interfered with the estimated surface temperature produced by the MOD11A2 product for Rio de Janeiro State in
2009: the Madden Julian Oscillation and South Atlantic Convergence Zone in the summer; and Frontal Systems, the South Atlantic Convergence Zone, the Madden Julian Oscillation and the Upper Tropospheric Cyclonic Vortex in spring.

The land use and occupation types with the highest surface temperature are: forest, urban area and pasture land in the summer; forest, urban area, agriculture and pasture land in autumn; and urban area and agriculture during spring. The MOD11A2 product showed a drastic decrease of the surface temperature for all land types during winter, especially for forested land.

RESUMO: Este artigo teve como objetivo avaliar a temperatura da superfície do solo usando o satélite MOD11A2 com resolução espacial de um quilômetro, comparar seus resultados com dados de temperatura da superfície terrestre adquiridas por estações meteorológicas convencionais, e, por fim, investigar as relações entre a temperatura da superfície da terra e eventos sistemas sinóticos que ocorreram no Estado do Rio de Janeiro entre janeiro até dezembro de 2009. As temperaturas mais elevadas da superfície obtidas pelo produto MOD11A2, derivado do sensor MODIS, foram encontrados nas regiões Metropolitana, Baixadas Litorâneas, Norte Fluminense e Noroeste Fluminense do Estado do Rio de Janeiro e foram registradas durante as estações de verão, inverno e primavera. $\mathrm{O}$ outono foi a única exceção devido à influência do ambiente costeiro. Os seguintes sistemas sinóticos interferiram na temperatura da superfície estimada pelo produto MOD11A2 para Estado do Rio de Janeiro em 2009: a Madden Julian Oscillation e Zona de Convergência do Atlântico Sul no verão; Sistemas frontais, a Zona de Convergência do Atlântico Sul, o Madden Julian Oscillation e o Alto Ciclone Vortéx Troposférico na primavera. Os tipos de uso e ocupação do solo com a temperatura da superfície mais alta são: floresta, área urbana e terras de pastagem no verão; floresta, área urbana, agricultura e pastagens no outono; área urbana e na agricultura durante a primavera. O produto MOD11A2 mostrou diminuição drástica da temperatura da superfície para todos os tipos de solo durante o inverno, especialmente para terrenos florestais.

PALAVRAS-CHAVE: Região sudeste. Sensoriamento remoto. Campo térmico. Satélites meteorológicos.

\section{REFERENCES}

ALLEN, R. G.; JENSEN, M. E.; BORNAN, R. D. Operational estimates of reference evapotranspiration. Agronomy Journal, Madson, v. 81, p. 650-662, 1989.

ANDRÉ, R. G. B.; MARQUES, V. S.; PINHEIRO, F. M. A.; FERRAUDO, A. S. Identificação de regiões pluviometricamente homogêneas no Estado do Rio de Janeiro, utilizando-se valores mensais. Revista Brasileira de Meteorologia, São José dos Campos, v. 23, p. 501-509, 2008.

ANJOS, A.W.; DELGADO, R. C.; OLIVEIRA-JÚNIOR, J. F.; GOIS, G.; MORAES, N. O. Temperatura da superfície continental associada aos eventos meteorológicos na cidade do Rio de Janeiro, RJ. Enciclopédia Biosfera, Goiânia, v. 9, n. 17, p. 3692-3707, 2013.

CPTEC - Centro de Previsão do Tempo e Estudos Climáticos. Boletim Climanálise. Disponível em: http://climanalise.cptec.inpe.br/ rclimanl/boletim/. Acesso em: 14 Ago 2013.

DELGADO, R.C.; SOUZA, L. P.; SILVA, I. W. R.; PESSÔA, C. S.; GOMES, FA. Influência da mudança da paisagem amazônica no aumento da precipitação em Cruzeiro do Sul, AC. Enciclopédia Biosfera, Goiânia, v. 8, p. 665-674, 2012.

FREITAS, E. D.; DIAS, P. L. S. Alguns Efeitos de Áreas Urbanas na Geração de uma Ilha de Calor. Revista Brasileira de Meteorologia, São José dos Campos, v. 20, p. 335-366, 2005. 
IBGE - Instituto Brasileiro de Geografia e Estatística. Censo Demográfico 2010. Disponível em:< http://www.ibge.gov.br>. Acesso em mar.2013.

INEA - Instituto Estadual do Ambiente. Base Temática. Disponível em: <

http://www.inea.rj.gov.br/basetematica_estadoambiente/>. Acesso em jun. 2013.

KATO, S.; YAMAGUCHI, Y. Analysis of urban heat-island effect using ASTER and ETM+ Data: Separation of anthropogenic heat discharge and natural heat radiation from sensible heat flux. Remote Sensing of Environment, Salt Lake City, v. 99, p. 44-54, 2005. https://doi.org/10.1016/j.rse.2005.04.026

LYRA, G. B.; SANTOS, M. J.; SOUZA, J. L.; LYRA, G. B.; SANTOS, M. A. Espacialização da temperatura do ar anual no estado de Alagoas com diferentes modelos digitais de elevação e resoluções espaciais. Ciência Florestal, Santa Maria, v. 21, p. 275-287, 2011. https://doi.org/10.5902/198050983231

MIRANDA, E. E. Brasil em Relevo. Campinas: Embrapa Monitoramento por Satélite, 2005. Disponível em: $<$ http://www.relevobr.cnpm.embrapa.br>. Acesso em: 02 set. 2013.

OLIVEIRA, J. B.; ARRAES, F. D. D.; VIANA, P. C. Methodology for the spatialisation of a reference evapotranspiration from SRTM data. Revista Ciência Agronômica, Fortaleza, v. 44, p. 445-454, 2013. https://doi.org/10.1590/S1806-66902013000300005

SATTERTHWAITE, D. Cities' contribution to global warming: notes on the allocation of greenhouse gas emissions. Environment and Urbanization, Tokyo, v. 20, p. 539-549, 2008.

https://doi.org/10.1177/0956247808096127

WAN, Z.; FENG, Y. Z.; ZHANG, Y.; KING, M. D. Land-surface temperature and emissivity retrieval from MODIS Airborne Simulator (MAS) data, Summaries of the Seventh JPL. Airborne Earth Science Workshop, Airborne, v. 3, p. 57-66, 1998.

WAN, Z. MODIS Land Surface Temperature Products Users' Guide Collection-5. ICESS, University of California, Santa Barbara, 2007.

WILLMOTT, C. J.; ACKLESON, S. G.; DAVIS, J. J.; FEDDEMA, J. J.; KLINK, K. M.; LEGATES, D. R.; O'DONNELL, J.; ROWE, C. M. Statistics for the evaluation and comparison of models. Journal of Geography Research, Malbourne, v. 90, p. 8995-9005, 1985.

ZERI, M.; OLIVEIRA-JÚNIOR, J. F.; LYRA, G. B. Spatiotemporal analysis of particulate matter, sulfur dioxide and carbon monoxide concentrations over the city of Rio de Janeiro, Brazil. Meteorology and Atmospheric Physics, Viena, v. 113, p. 1-14, 2013. 